\title{
Nearshore Temperature Findings for the Colorado River in Grand Canyon, Arizona-Possible Implications for Native Fish
}

\author{
ince the completion of Glen Canyon \\ Dam, Arizona, in 1963, downstream \\ water temperatures in the main channel \\ of the Colorado River in Glen, Marble, \\ and Grand Canyons are much colder in \\ summer. This has negatively affected \\ humpback chub (Gila cypha) and other \\ native fish adapted to seasonally warm \\ water, reducing main-channel spawning \\ activity and impeding the growth and \\ development of larval and juvenile fish. \\ Recently published studies by U.S. \\ Geological Survey scientists found that \\ under certain conditions some isolated \\ nearshore environments in Grand \\ Canyon allow water to separate from \\ the main-channel current and to warm, \\ potentially providing refuge areas for the \\ development of larval and juvenile fish.
}

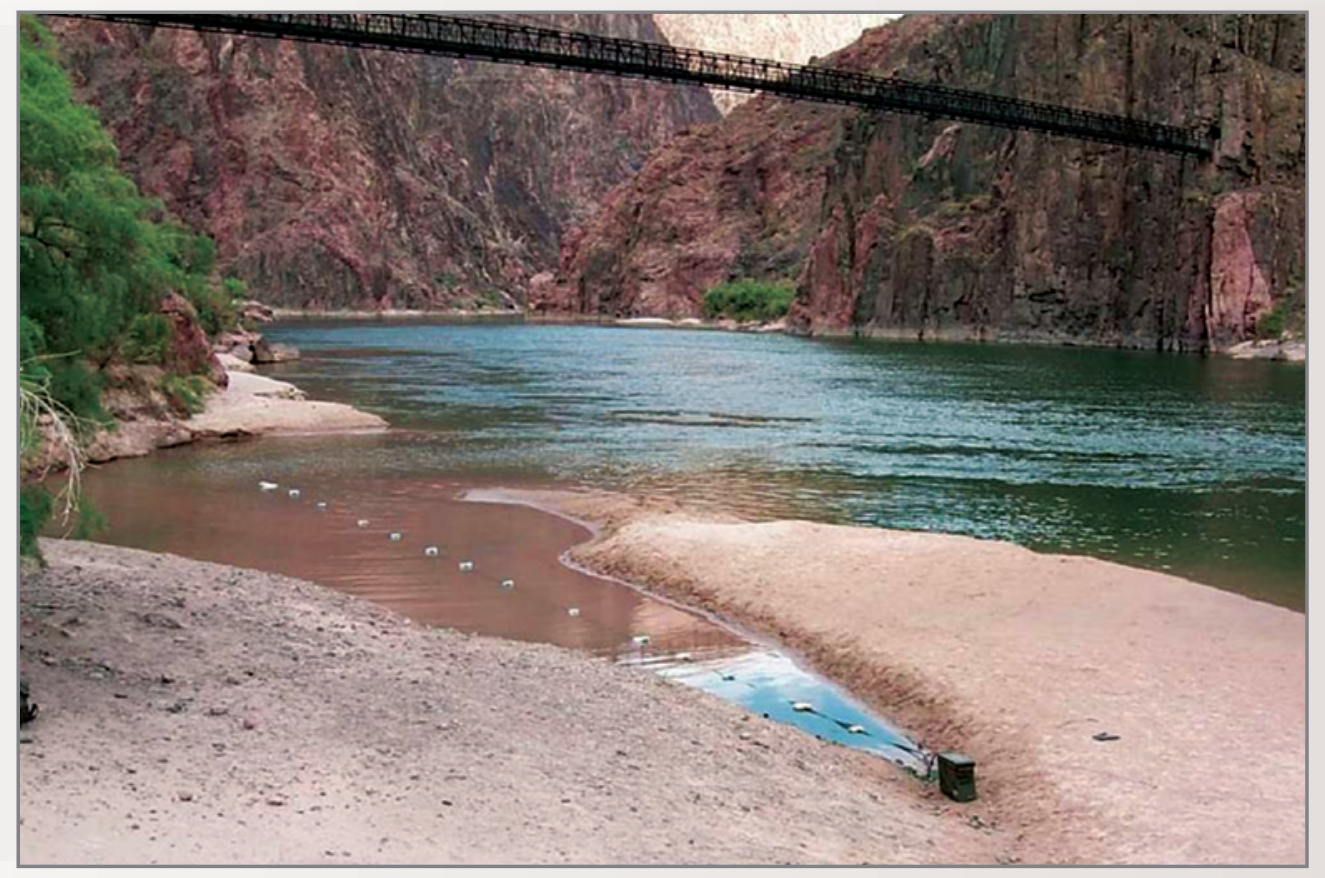

This backwater site-at river mile 87.4 in the Colorado River in Grand Canyon, Arizona-was monitored using the approximately 80 -foot string of temperature sensors shown in the photo. The monitoring determined nearshore temperatures during the Low Steady Summer Flow water release experiment from Glen Canyon Dam in 2000. The backwater, isolated by the sand spit protruding upstream, had significant warming during the study period. Warming in such nearshore areas may be important for the growth and survival of native fish, such as the endangered humpback chub (Gila cypha; see inset photo of juvenile below). The Kaibab Suspension Bridge can be seen overlooking the river. (U.S. Geological Survey photograph by William S. Vernieu; inset photograph courtesy of Jared Flowers, North Carolina State University.)

Glen Canyon Dam impounds the Colorado River upstream from Glen, Marble, and Grand Canyons, Arizona, and forms Lake Powell reservoir. Water temperatures in the pre-dam Colorado River ranged from 32 degrees Fahrenheit $\left({ }^{\circ} \mathrm{F}\right)$ in the winter to more than $86^{\circ} \mathrm{F}$ in the summer. Fixed location penstocks (water intakes) in the dam now withdraw cold water from deep within Lake Powell to generate hydropower. When the reservoir is full, at an elevation of 3,700 feet, waterrelease temperatures are confined to a small range ( 45 to $54^{\circ} \mathrm{F}$ ). However, on October 14, 2005, 6 months after the reservoir reached a historic low level of 3,555 feet, the annual maximum daily average release temperature was $61^{\circ} \mathrm{F}$. These figures represent the warmest release temperatures and lowest reservoir levels since the early filling stages of Lake Powell and show the relatively strong linkage between reservoir level and release temperature.
The Colorado River in Marble and Grand Canyons supports a distinctive aquatic ecosystem that includes native and non-native organisms. Today, some native fish species are no longer found in Marble and Grand Canyons, but the humpback chub (Gila cypha) persists, although the species is listed as endangered. Temperature is an important control on humpback chub spawning, as well as juvenile and larval growth rates, although other factors in nearshore environments, such as turbidity (water clarity) and physical protection from predation, also affect the life history of this species (Dodrill, 2012).

Today's colder and less variable water temperatures are an important factor in preventing humpback chub from spawning in the Colorado River and limit growth rates of larval and juvenile fish. However, there is a potential for pockets of relatively warm water to develop near the channel banks where stream flow decelerates, takes

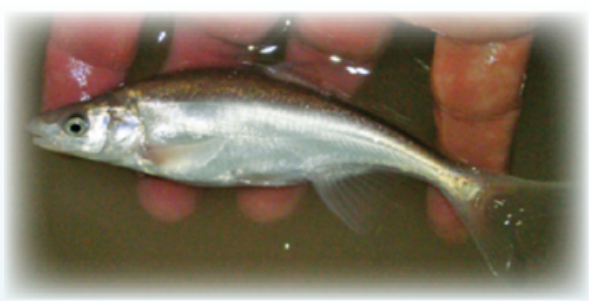

longer to mix back into the main-channel current, and is allowed more opportunity to warm. These nearshore environments are potentially important for humpback chub rearing. There are several types of nearshore habitat, and some areas are isolated from the cold main channel, and flow is nearly stagnant. In these areas, mixing with the main channel is most limited, and the potential for warming from heat exchange with ambient air or direct sunlight is greatest. Elsewhere, nearshore areas are not isolated from the main channel, and although these areas may have lower water velocities, there is strong mixing with the cold main channel. 


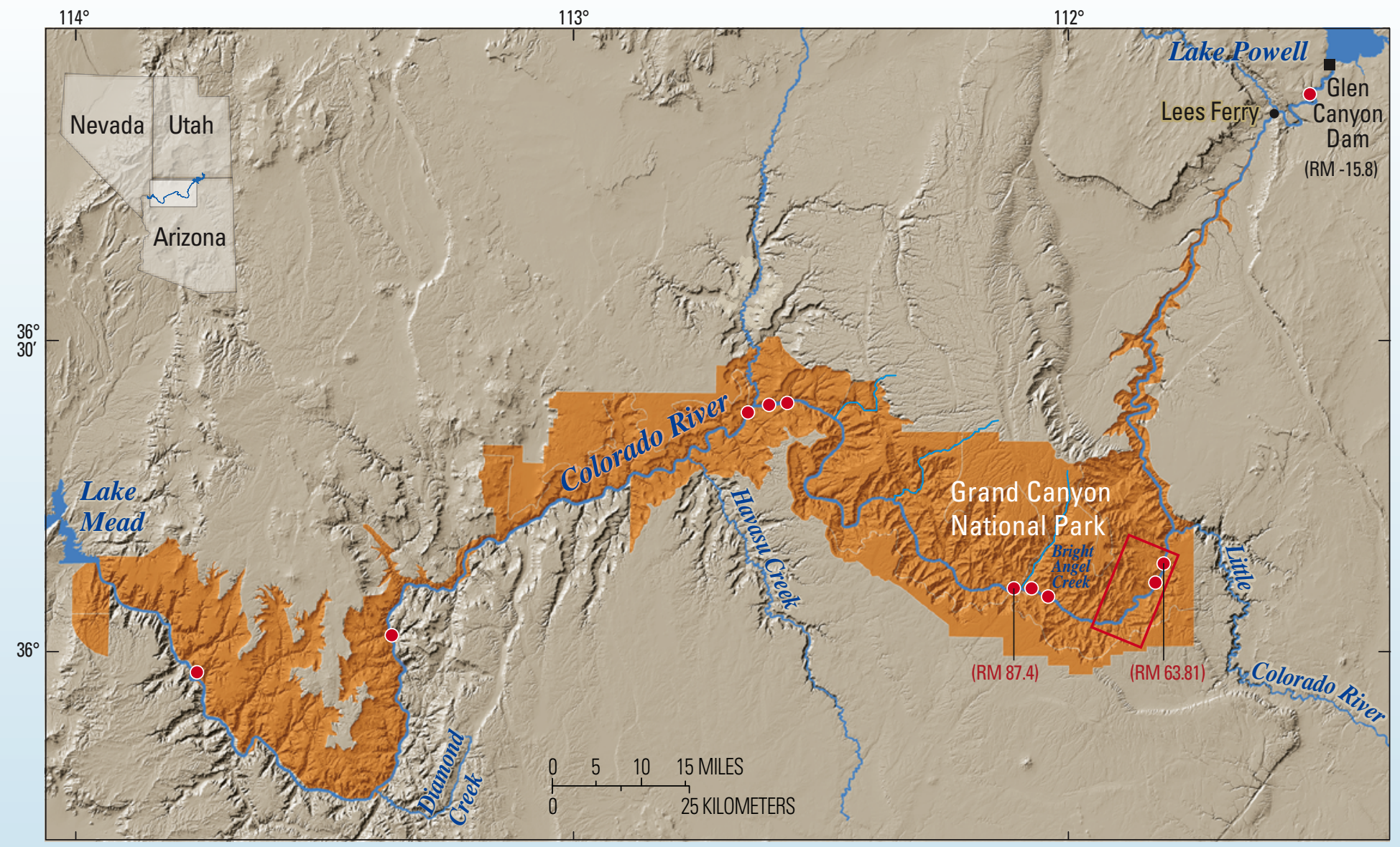

Map of the Colorado River downstream of Glen Canyon Dam showing the river corridor between Lake Powell and Lake Mead reservoirs and areas where U.S. Geological Survey scientists recently studied nearshore temperatures in areas potentially important for the survival of native fish. Dots indicate sites studied by Vernieu and Anderson (2013) in 2000, and the red box is the area studied by Ross and Grams (2013) in 2010. (RM, river mile.)

\section{Downstream and Nearshore Trends in Main-Channel Temperature}

Studies of water temperatures throughout Glen, Marble, and Grand Canyons by U.S. Geological Survey Grand Canyon Monitoring and Research Center (GCMRC) scientists and cooperators document downstream trends in mainchannel temperatures. In spring, summer, and fall, the Colorado River gets progressively warmer downstream by solar warming (insolation) and by heat exchange between warmer air and colder water. In summer, the water may warm by as much as $0.058^{\circ} \mathrm{F}$ per river mile. In winter months, when the air is colder than the water, temperatures in the main channel may decrease in the downstream direction (Voichick and Wright, 2007). Using Lake Powell release temperature, release volume (monthly average flow), and monthly average air temperature as inputs, downstream trends in main-channel temperature can be predicted by a simple numerical model (Wright and others, 2009). The model is used by the Bureau of Reclamation and by stakeholders of the Glen Canyon Dam Adaptive

Management Program to predict average monthly water temperatures throughout Marble and Grand Canyons.

Although the model can predict the general downstream trend of the mainchannel temperature of the Colorado River, there can be large variability in temperature between the main channel and the nearshore areas (Schmidt and Graf, 1990; Yard and others, 2005; Behn and others, 2010). For some river management issues and for purposes of better understanding the aquatic ecosystem and spatial variability of water temperature, direct measurements of nearshore water temperatures have been made in parts of Marble and Grand Canyons. Korman and others (2006) suggested that nearshore temperature varies in relation to shoreline characteristics, with increased warming in isolated shoreline environments, slight warming in low-angle sandy shorelines, and no substantial warming in non-isolated shoreline environments. Behn and others (2010) conducted experiments to measure how quickly the water in a few isolated shoreline environments mixed with the water in the main channel. They investigated areas ecologists call "backwaters," which are areas of near-stagnant flow that are usually separated from the main channel by a sandbar. They found that the water in small, shallow backwaters was completely mixed with the main channel in less than 5 minutes and that the water in large, deep backwaters of irregular shape can take as much as 28 hours to mix with the main channel. They also found that the mixing time, also called "residence time," was longer during steady flows than during flows that fluctuate in response to hydroelectricity demand. Water in locations with longer mixing times is expected to be warmer relative to the main channel than the water in other locations that have more mixing.

\section{Recent Findings-Temperature in Nearshore Environments}

To further clarify the magnitude of nearshore warming throughout Glen, Marble, and Grand Canyons, GCMRC scientists monitored different types of 
nearshore environments for time intervals of as much as 50 hours during the Low Steady Summer Flow experiment of 2000 (Vernieu and Anderson, 2013), which was conducted to evaluate the effects of the experimental flow on physical and biological resources of the Colorado River ecosystem downstream from Glen Canyon Dam. The purpose of the study was to measure the magnitude of warming above main-channel temperatures under steady-flow conditions. Measurement sites included those where there was a significant potential for nearshore warming. Types of environments ranged from areas adjacent to main-channel currents to isolated backwaters. River flows were steady at about 8,000 cubic feet per second during the study. Water temperature was measured by sensors spaced about 1.5 to 15 feet apart, with closer spacing nearer to shore, along lines about 15 to 80 feet in length anchored in the river.

These measurements showed that significant warming occurred in those nearshore areas that are isolated from main-channel currents and exposed to solar radiation. In other words, if a nearshore area was separated from the main-channel current and if water exchange rates with the main channel were low, nearshore temperatures increased as long as those environments were in direct sunlight. In the absence of direct sunlight, most nearshore areas exhibited similar temperatures to the main channel. In some areas, such as at the backwater near the Bright Angel Creek boat beach at river mile (RM) 87.4 (as measured downstream from Lees Ferry), there was enough isolation of the backwater to maintain elevated temperatures overnight. At this site, warming of $23^{\circ} \mathrm{F}$ above mainchannel temperature occurred, mainly in a small isolated area (toe) of the backwater. Elsewhere, there was little or no nearshore warming where there was rapid water exchange between the nearshore area and the main channel.

Ross and Grams (2013) made temperature measurements in the summerfall of 2010 at eight locations in a 2.5-mile reach of the Colorado River, from RM 63.3 to RM 65.8, a short distance downstream from the confluence of the Little Colorado River. The purpose of the study was to better understand temperature gradients in nearshore areas that are not isolated from the main channel, because this reach is an important rearing area for juvenile humpback chub that disperse from the Little Colorado River. Measurements were made along bedrock cliffs, talus slopes, cobble bars, and debris fans. All sites had some degree of river current ranging from fast downstream-oriented currents to weak eddy currents. Water temperatures were measured using sensors spaced at regular intervals along lines anchored in the river and were monitored during three separate intervals from July through October 2010. Reservoir releases were of high volume and fluctuating in July and August and were of low volume and steady in September and October. These same shoreline habitat types were also sampled for native and non-native fish (for example, Dodrill, 2012).

Significant nearshore warming was not observed in any of the shoreline environments. Temperature differences between the main channel and the temperature sensor about 1.5 feet from the shoreline were much less than $1.8^{\circ} \mathrm{F}$ in all monitoring periods. This indicates that the water in all of the nearshore areas monitored in this study was sufficiently well mixed with the main channel to prevent significant warming. Some warming was observed in areas less than about 1.5 feet from the shoreline, but these areas were not monitored consistently because shoreline fluctuation and generally very shallow water conditions led to periods in which the data gathered were inconclusive.

\section{Management Implications}

These recent findings demonstrate that the magnitude of nearshore warming in the Colorado River is greatly affected by the local geomorphology (structure and type) of the banks, and significant warming only occurs in places where there is little exchange of flow between the cold main channel and areas of nearly stagnant water. Backwaters that occur in the lee (downstream side) of sandbars or in wide shallow areas under flow regimes with small daily fluctuations in water level are important locations where nearly stagnant water occurs. Management of nearshore environments to increase the area of relatively warm water in an otherwise cold river would require manipulation of reservoir releases and (or) nearshore habitats to create pockets of stagnant water.

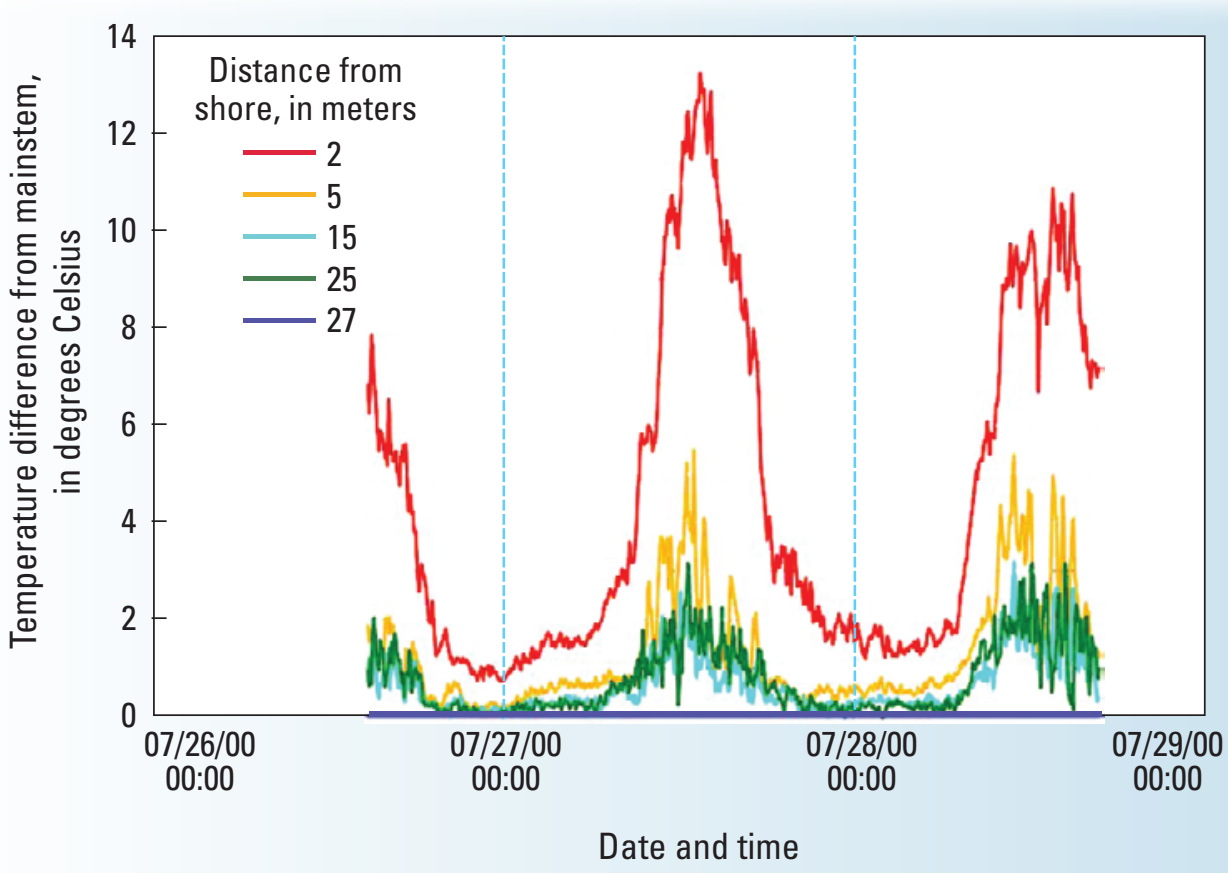

Graph showing water-temperature patterns for the backwater site at river mile 87.4 along the Colorado River in Grand Canyon during the Low Steady Summer Flow experiment of 2000 (Vernieu and Anderson, 2013). Each data-series line corresponds to temperature sensors at the indicated distance from the toe (most isolated part) of the backwater. The dark blue dataseries line from a sensor 27 meters (about 90 feet; 1 meter is about 3.28 feet) from shoreline represents the main channel. Temperature is shown as differences from main-channel temperature in degrees Celsius $\left[{ }^{\circ} \mathrm{C}\right.$; temperature difference in degrees Fahrenheit $\left({ }^{\circ} \mathrm{F}\right)=$ $1.8 x^{\circ} \mathrm{C}$ ]. The graph shows significant warming during daylight hours over the approximately 2-day study period in July 2000 (as much as $13^{\circ} \mathrm{C}$, or $23^{\circ} \mathrm{F}$ ) and indicates that the warming decreased greatly in the overnight parts of the study (to a difference of about $1^{\circ} \mathrm{C}$, or $1.8^{\circ} \mathrm{F}$ ). 
Warming occurs during steady flows from Glen Canyon Dam in low-velocity nearshore environments of the Colorado River that are both disconnected from the main channel and in direct sunlight (Vernieu and Anderson, 2013). Warming of these environments may occur under fluctuating flows, but the areas warmed are less persistent than under steady flows (Behn and others, 2010). Under steady-flow conditions, temperatures in these environments generally revert to those of the main channel when the sun sets at night (Vernieu and Anderson, 2013). Nearshore areas not disconnected from the main channel do not warm significantly under steady or fluctuating flows (Ross and Grams, 2013; Vernieu and Anderson, 2013).

These findings suggest that significant warming only occurs in isolated nearshore environments during daylight, with warming reversing after sunset. The potential for warming in backwater areas is greatest during the warmest months and at steady low-flow conditions.

\section{Next Steps}

Nearshore environments are potentially important habitats for native fish in the Colorado River below Glen Canyon Dam. Some amount of warming in these environments may be helpful to the growth and development of larval and juvenile fish, but the role of temporary warming in narrow nearshore areas in the life history of native fish species is not yet well understood. Other factors such as mainchannel water temperature, food sources, cover from predators, refuge from river currents, and the presence of non-native species may also be important. In the dramatically changed post-Glen Canyon Dam ecosystem, all of these factors may play a significant role in the survival and recovery of native fish in Grand Canyon.

\section{References Cited}

Behn, K.E., Kennedy, T.A., and Hall, R.O., Jr., 2010, Basal resources in backwaters of the Colorado River below Glen Canyon DamEffects of discharge regimes and comparison with mainstem depositional environments: U.S. Geological Survey Open-File Report 20101075, 25 p., http://pubs.usgs.gov/of/2010/1075/.

Dodrill, M.J., 2012, Habitat relationships of small bodied fish in the Grand Canyon reach of the Colorado River, Arizona-Emphasis on native fish and evaluation of backwater habitats: University of Florida, Gainesville, unpublished M.S. thesis, 106 p., accessed August 29, 2013, at http://ufdc.ufl.edu/UFE0044372/00001/pdf.

Korman, J., Kaplinski, M., and Buszowski, J., 2006, Effects of air and mainstem water temperatures, hydraulic isolation, and fluctuating flows from Glen Canyon Dam on water temperatures in shoreline environments of the Colorado River in Grand Canyon: Ecometric Research Inc., Northern Arizona University, and Namtek Inc., submitted to U.S. Geological Survey, Grand Canyon Monitoring and Research Center, Flagstaff, Ariz., cooperative agreement no. 04WRAG00006, modification 1, 52 p., accessed August 29, 2013, at http://www.gcmrc. gov/library/reports/physical/Water_Temperature/ Korman2006b.pdf.

Ross, R.P., and Grams, P.E., 2013, Nearshore thermal gradients of the Colorado River near the Little Colorado River confluence, Grand Canyon National Park, Arizona: U.S. Geological Survey Open-File Report 2013-1013, 65 p., http://pubs. usgs.gov/of/2013/1013/.

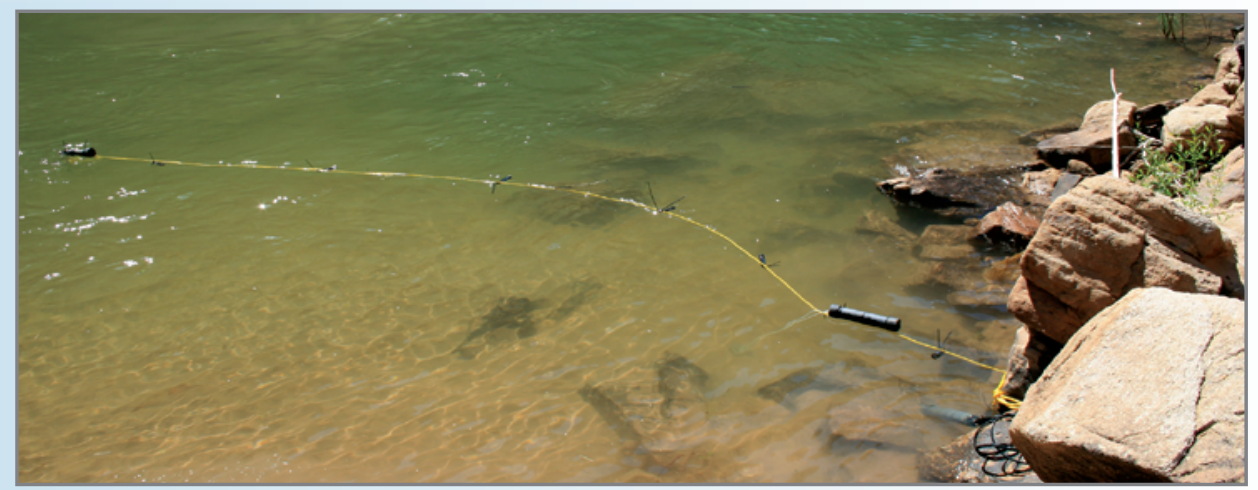

Photograph showing a string of temperature sensors at river mile 63.81 used in 2010 by Ross and Grams (2013) to study water temperatures in nearshore areas that native fish may occupy. The downstream bow of the string shows the influence of the river's current and that this site is not isolated from main channel. This site had no significant warming during either fluctuating or nonfluctuating flows from Glen Canyon Dam. (U.S. Geological Survey photograph by Robert P. Ross.)

Schmidt, J.C., and Graf, J.B., 1990, Aggradation and degradation of alluvial sand deposits, 1965 to 1986, Colorado River, Grand Canyon National Park, Arizona: U.S. Geological Survey Professional Paper 1493, 74 p., http://pubs. er.usgs.gov/publication/pp1493/.

Vernieu, W.S., and Anderson, C.R., 2013, Water temperatures in select nearshore environments of the Colorado River in Grand Canyon, Arizona, during the Low Steady Summer Flow experiment of 2000: U.S. Geological Survey Open-File Report 2013-1066, 44 p., http://pubs. usgs.gov/of/2013/1066/.

Voichick, N., and Wright, S.A., 2007, Watertemperature data for the Colorado River and tributaries between Glen Canyon Dam and Spencer Canyon, northern Arizona, 1988-2005: U.S. Geological Survey Data Series 251, 24 p., http://pubs.usgs.gov/ds/2007/251/.

Wright, S.A., Anderson, C.R., and Voichick, N., 2009, A simplified water temperature model for the Colorado River below Glen Canyon Dam: River Research and Applications, v. 25, p. 675-686, doi: 10.1002/rra.1179.

Yard, M.D., Bennett, G.E., Mietz, S.N., Coggins, L.G., Jr., Hueftle, S.J., and Blinn, D.W., 2005, Influence of topographic complexity on solar insolation estimates for the Colorado River, Grand Canyon, AZ: Ecological Modeling, v. 183, p. 157-172, doi: 10.1016/j. ecomodel.2004.07.027.

Robert P. Ross and William S. Vernieu

Edited by James W. Hendley II

Graphics and layout by Jeanne S. DiLeo

For more information contact: U.S. Geological Survey Southwest Biological Science Center Grand Canyon Monitoring and Research Center 2255 N. Gemini Drive Flagstaff, AZ 86001 (928) 556-7094 http://www.gcmrc.gov/

This fact sheet and any updates to it are available

online at http://pubs.usgs.gov/ fs/2013/3104/ 